\title{
Prognostic value of proliferating cell nuclear antigen in gastric carcinoma
}

\author{
S Jain, M I Filipe, P A Hall, N Waseem, D P Lane, D A Levison
}

\begin{abstract}
A new monoclonal antibody to proliferating cell nuclear antigen (PCNA), PC10, which can be used on routinely processed tissue, was applied to 93 cases of gastric carcinoma. Significant intratumoural variation in staining occurred. In addition to a PCNA index (percentage of positive cells per 1000 tumour cells), a semiquantitative PCNA grading system was devised, based on estimates of less than or more than $50 \%$ of positive tumour cells in whole sections. Neither PCNA index nor PCNA grade showed any correlation with established histological variables, tumour stage, or the presence of lymph node metastases. No significant correlation was observed between PCNA index and $S+G_{2} M$ phase fraction measured by flow cytometric analysis. To analyse survival tumours with PCNA indices above and below the median level (41\%) were compared. Those with a higher index tended to have a worse prognosis, but when PCNA grade was considered, it was found to have definite independent prognostic value, tumours of low grade surviving better than those of high grade. The ability of semiquantitative PCNA grading to allow for intratumoural variation suggests it may have advantages over absolute counting, which is prone to sampling error when tumour heterogeneity is a major factor. The prognostic value of PC10 staining in gastric carcinoma is therefore promising.
\end{abstract}

Gastric carcinoma is the fourth most common cause of cancer death in the United Kingdom ${ }^{1}$ and is second only to lung cancer, worldwide. ${ }^{2}$ The prognosis of gastric cancer, once it has reached an advanced stage with invasion of the muscle layer, is particularly poor with an overall five year survival of only $11 \%$. Morphological criteria such as histological type, histological grade, and growth pattern have been used in the assessment of gastric cancer but can't be used to predict clinical outcome. ${ }^{3}$

Information on cell kinetics may be a useful adjunct to histologically based tumour classifications in the understanding of tumour behaviour. In a variety of malignant neoplasms correlations have been noted between proliferative activity and metastatic potential, recurrence and overall prognosis. ${ }^{4}$ Current methods of assessing the proliferation and growth of tumours require in vitro or in vivo labelling with $\mathrm{H}^{3}$-thymidine or its nonradioactive analogue, bromodeoxyuridine, or cryostat sections of fresh frozen material (Ki67 , or disruption of cellular and tissue architecture (DNA flow cytometry). ${ }^{45}$ These caveats have limited the use of such methods on archival material and in routine diagnosis.

Autoantibodies in patients with systemic lupus erythematosus (SLE) recognise an auxiliary protein of DNA polymerase $\delta$, also known as proliferating cell nuclear antigen (PCNA). PCNA is present in nuclei throughout the cell cycle and is synthesised in late Gl and S-phase, levels therefore correlating with the cell's proliferative state. ${ }^{67} \mathrm{~A}$ monoclonal antibody (PC10) has been described which recognises PCNA in routinely fixed, paraffin wax embedded tissues. ${ }^{89}$ It has also been suggested recently that the PCNA index may be useful in certain tumours as an independent prognostic variable. ${ }^{1011}$

\section{Methods}

Samples of advanced gastric carcinoma were available from 93 patients who underwent gastrectomy at Guy's Hospital between 1979 and 1989. No patient had received chemotherapy or radiotherapy before surgery. Fiftyeight men and 35 women $(1.66: 1)$ with a mean age 64 (29-88 years) were studied.

The tumours were classified according to histological type (intestinal or diffuse), ${ }^{12}$ growth pattern (expansive or infiltrative), ${ }^{13}$ and degree of differentiation (well, moderate, or poor).$^{14}$ Eleven of the tumours had invaded only as far as the muscularis propria while the other 82 had reached the serosa. Lymph node metastases were present in 74 cases.

All tissue was routinely fixed in $10 \%$ formalin and paraffin wax embedded. Sections were cut at $5 \mu \mathrm{m}$, mounted on poly-L-lysine coated glass slides, and air dried overnight at room temperature. Oven drying at $60^{\circ} \mathrm{C}$ for one hour greatly reduces the PCNA immunoreactivity. ${ }^{9}$

PCNA staining was performed using a rapid LSAB kit (Dako). Sections were dewaxed in xylene, rehydrated through alcohol, and then immersed in 3\% hydrogen peroxide in methanol for 10 minutes to block endogenous peroxidase activity. Sections were subsequently washed in phosphate buffered saline (PBS), and normal goat serum was applied for 10 minutes to reduce non-specific 
antibody binding. PC10 was used at a concentration of $0.5 \mu \mathrm{g} / \mathrm{ml}$ for 10 minutes at room temperature. Biotinylated goat anti-mouse antibody was used as the linker molecule and was applied at a dilution of 1 in 100 for 10 minutes. After further washing, sections were incubated in streptavidin-horseradish peroxidase complex (Cambridge Biosciences) at a 1 in 100 dilution for 10 minutes. Diaminobenzidine-hydrogen peroxide (Sigma) was used as chromogen and a light Mayer's haematoxylin counterstain applied. Sections were dehydrated in alcohol, cleared in xylene, and mounted in DPX.

To ensure consistency of PCNA staining between batches a known positive control gastric carcinoma was included in each round. The experiment was repeated if there was any measurable fluctuation in the PCNA index of this control. Negative controls were included by performing duplicate assays, on one of which the primary antibody was replaced by PBS.

\section{ASSESSMENT OF PCNA STAINING}

Sections were counted at high power $(\times 400)$ and eight fields/tumour were chosen at random. Nuclei from 1000 tumour cells were counted in each case with the aid of an eyepiece graticule. The PCNA index was calculated as the percentage of positive tumour cell nuclei. Ten cases were counted by two independent observers and on three separate occasions by the same observer to estimate inter- and intra-observer variation, respectively. The heterogeneity of some tumours meant that areas of the same section often dispayed widely different counts. For this reason a semiquantitative PCNA grading system was devised in which the whole of a section was assessed at a lower power $(\times 100)$ in an effort to take better account of tumour heterogeneity. Tumours were allocated a low PCNA grade if the observer assessed less than $50 \%$ of tumour cell nuclei to be positive, or a high PCNA grade if more than $50 \%$ were estimated to be positive. All tumours were graded by two observers and grading was done before counting in almost all cases.

Flow cytometry was performed in 54 cases as described in Hedley et $a l^{15}$ and Ormerod et $a l .{ }^{16}$ The analysis was carried out using an Ortho Cytofluorograft $50 \mathrm{H}$ equipped with a $50 \mathrm{mw}$ Lexel argon-ion laser tuned to $488 \mathrm{~nm}$ and measuring forward and orthogonal light scatter and red fluorescence. The proportion of $S+G_{2} M$ fraction was calculated from the DNA histograms, as described previously. ${ }^{17}$

Survival data were obtained for 91 patients, follow up times varying between six and 121 months. Sixty eight $(73 \%)$ of the patients had been followed up for a minimum of five years. The effect of various parameters on clinical outcome was assessed by plotting actuarial survival curves, and groups were compared using the logrank test; ${ }^{18}$ for multifactorial analysis Cox's proportional hazards model was applied. ${ }^{19}$

\section{Results}

PCNA staining was confined to nuclei (fig 1). Though some cells stained more strongly than others, all identifiable staining was regarded as positive. PCNA positivity showed pronounced intertumoural variation and the PCNA index varied within a range of $0-91 \%$ with a mean (SD) value of $40.73(25.51)$. Similarly, there was noticeable intratumoural heterogeneity in
Figure 1 Gastric carcinoma of intestinal type stained with PC10 antibody and showing nuclei expressing PCNA ( $A B C$ immunoperoxidase method).

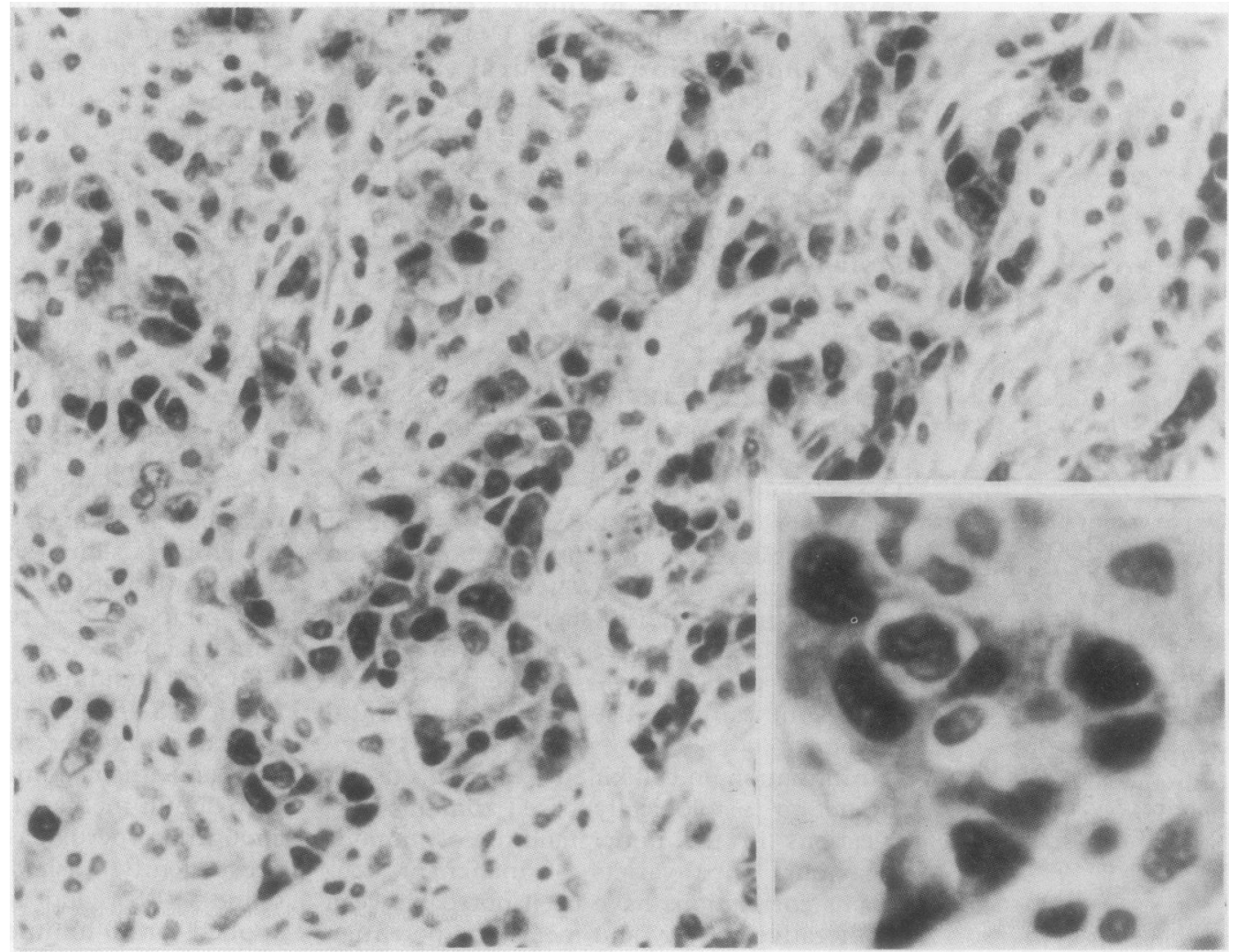


Table 1 Types of variation found when assessing $P C N A$ index

\begin{tabular}{lrl}
\hline & \multicolumn{2}{l}{ Standard deviation } \\
\cline { 2 - 3 } & Mean & Maximum \\
\hline Intertumoural & 25.51 & 91 \\
Intratumoural & 9.41 & 32.04 \\
Intraobserver & 6.91 & 14.84 \\
Interobserver & 9.59 & 16.16 \\
\hline
\end{tabular}

a significant number of cases. The average intratumoural variation among the eight random fields counted in each tumour was $9 \cdot 41$ (mean pooled SD). This rose to a maximum of 32.04 , that is greater than the intertumoural variation and shows a significant level of intratumoural heterogeneity. The values for intra- and inter-observer variation were 6.91 and $7 \cdot 59$, respectively (table 1 ).

Semiquantitative PCNA grading, which took into account intratumoural variation, showed $71 \%$ concordance with the PCNA index. Most of the disagreement involved the tumour being given a lower grade than its PCNA index would have suggested.

Most tumours (72\%) were of low PCNA grade. There was a $90 \%$ concordance between the two observers in relation to allocation of the tumours to low or high PCNA grade. Attempts to subdivide tumours into four PCNA grades (0-25\%, 26-50\%, 51-75\%, 75-100\% positive tumour cells) resulted in only $30 \%$ concordance between the two observers; therefore the two grade system was used in the analysis.
Neither PCNA index nor PCNA grade seemed to show any relation with other clinicopathological variables (table 2 ). The range of values of the PCNA index was very large (at least 1-89) in all subsets, leading to correspondingly high standard deviations. Differences in the mean PCNA index among these groups were small and not significant. Similarly, when PCNA grade was considered, none of the histological subtypes nor stages showed significantly different patterns (table 3 ). Cell cycle analysis using flow cytometry showed no significant correlation between PCNA index and $S+G_{2} M$ fraction $(p=0 \cdot 2)$.

To evaluate the association between PCNA index and patient survival tumours were separated on the basis of the median value (41). Forty six tumours had a "high" PCNA index of more than 41 and 47 a "low" PCNA index of less than 41. Patients whose tumours had a "low" PCNA index seemed to have a better prognosis but this was not significant $(\mathrm{p}=0.3$ ) (fig 2). When tumours were divided above and below the $50 \%$ PCNA index, there was very little difference between the survival of the two groups. In contrast, increasing the PCNA grade seemed to have a definite adverse effect on prognosis ( $p<0.02$ ) (fig 3).

\section{Discussion}

The major advantage of staining with PC10 antibody to PCNA is its applicability to formalin fixed tissues, permitting study of archival

Table 2 Correlation between PCNA index and established pathological variables

\begin{tabular}{|c|c|c|c|c|}
\hline & \multirow[b]{2}{*}{$\begin{array}{l}\text { Number of } \\
\text { tumours }\end{array}$} & \multicolumn{3}{|c|}{$P C N A$ index } \\
\hline & & Mean & $\begin{array}{l}\text { Standard } \\
\text { deviation }\end{array}$ & Range \\
\hline All tumours & 93 & $40 \cdot 73$ & $25 \cdot 51$ & $0-91$ \\
\hline $\begin{array}{l}\text { Histological type: } \\
\text { Intestinal } \\
\text { Diffuse }\end{array}$ & $\begin{array}{l}53 \\
40\end{array}$ & $\begin{array}{l}41 \cdot 53 \\
39.67\end{array}$ & $\begin{array}{l}25 \cdot 55 \\
25 \cdot 75\end{array}$ & $\begin{array}{l}0-91 \\
1-89\end{array}$ \\
\hline Growth pattern: & & & & \\
\hline $\begin{array}{l}\text { Expanding } \\
\text { Infiltrative }\end{array}$ & $\begin{array}{l}42 \\
51\end{array}$ & $\begin{array}{l}43.98 \\
38.06\end{array}$ & $\begin{array}{l}25 \cdot 05 \\
25 \cdot 82\end{array}$ & $\begin{array}{l}0-91 \\
0-89\end{array}$ \\
\hline Differentiation: & & & & \\
\hline $\begin{array}{l}\text { Well/moderate } \\
\text { Poor }\end{array}$ & $\begin{array}{l}36 \\
57\end{array}$ & $\begin{array}{l}44 \cdot 44 \\
38 \cdot 38\end{array}$ & $\begin{array}{l}26 \cdot 58 \\
25 \cdot 62\end{array}$ & $\begin{array}{l}0-91 \\
0-89\end{array}$ \\
\hline Depth of invasion: & & & & \\
\hline $\begin{array}{l}\text { Muscle } \\
\text { Serosa }\end{array}$ & $\begin{array}{l}11 \\
82\end{array}$ & $\begin{array}{l}44 \cdot 50 \\
40 \cdot 22\end{array}$ & $\begin{array}{l}33 \cdot 50 \\
24 \cdot 46\end{array}$ & $\begin{array}{l}1-91 \\
0-90\end{array}$ \\
\hline Metastases: & & & & \\
\hline $\begin{array}{l}\text { Positive } \\
\text { Negative }\end{array}$ & $\begin{array}{l}74 \\
19\end{array}$ & $\begin{array}{l}39 \cdot 22 \\
46 \cdot 63\end{array}$ & $\begin{array}{l}24 \cdot 00 \\
30 \cdot 73\end{array}$ & $\begin{array}{l}0-89 \\
1-91\end{array}$ \\
\hline
\end{tabular}

Table 3 Correlation between PCNA grade and established pathological variables

\begin{tabular}{|c|c|c|c|c|c|}
\hline & \multirow{2}{*}{$\begin{array}{l}\text { Number of } \\
\text { tumours }\end{array}$} & \multicolumn{4}{|c|}{ PCNA grade } \\
\hline & & 1 & 2 & 3 & 4 \\
\hline $\begin{array}{l}\text { All tumours } \\
\text { Histological type: }\end{array}$ & 93 & $33(35 \%)$ & $34(37 \%)$ & $21(23 \%)$ & $5(5 \%)$ \\
\hline $\begin{array}{l}\text { Intestinal } \\
\text { Diffuse } \\
\text { Growth pattern: }\end{array}$ & $\begin{array}{l}53 \\
40\end{array}$ & $\begin{array}{l}18(34 \%) \\
15(37 \%)\end{array}$ & $\begin{array}{l}20(38 \%) \\
14(35 \%)\end{array}$ & $\begin{array}{r}12(23 \%) \\
9(23 \%)\end{array}$ & $\begin{array}{l}3(6 \%) \\
2(5 \%)\end{array}$ \\
\hline $\begin{array}{l}\text { Expanding } \\
\text { Infiltrative }\end{array}$ & $\begin{array}{l}42 \\
51\end{array}$ & $\begin{array}{l}12(29 \%) \\
21(41 \%)\end{array}$ & $\begin{array}{l}19(45 \%) \\
15(30 \%)\end{array}$ & $\begin{array}{r}7(17 \%) \\
14(27 \%)\end{array}$ & $\begin{array}{l}4(9 \%) \\
1(2 \%)\end{array}$ \\
\hline $\begin{array}{l}\text { Differentiation: } \\
\text { Well/moderate } \\
\text { Poor } \\
\text { Depth of invasion: }\end{array}$ & $\begin{array}{l}36 \\
57\end{array}$ & $\begin{array}{l}12(33 \%) \\
21(37 \%)\end{array}$ & $\begin{array}{l}12(33 \%) \\
22(39 \%)\end{array}$ & $\begin{array}{r}9(25 \%) \\
12(21 \%)\end{array}$ & $\begin{array}{l}3(9 \%) \\
2(3 \%)\end{array}$ \\
\hline $\begin{array}{l}\text { Muscle } \\
\text { Serosa } \\
\text { Metastases: }\end{array}$ & $\begin{array}{l}11 \\
82\end{array}$ & $\begin{array}{r}6(54 \%) \\
27(33 \%)\end{array}$ & $\begin{array}{r}2(18 \%) \\
32(39 \%)\end{array}$ & $\begin{array}{c}0(0 \%) \\
21(26 \%)\end{array}$ & $\begin{array}{l}3(28 \%) \\
2(2 \%)\end{array}$ \\
\hline $\begin{array}{l}\text { Positive } \\
\text { Negative }\end{array}$ & $\begin{array}{l}74 \\
19\end{array}$ & $\begin{array}{r}27(36 \%) \\
6(32 \%)\end{array}$ & $\begin{array}{r}27(36 \%) \\
7(37 \%)\end{array}$ & $\begin{array}{r}17(23 \%) \\
4(21 \%)\end{array}$ & $\begin{array}{l}3(4 \%) \\
2(10 \%)\end{array}$ \\
\hline
\end{tabular}


Figure 2 Comparative survival of patients related to tumour PCNA indices above or below the median level.

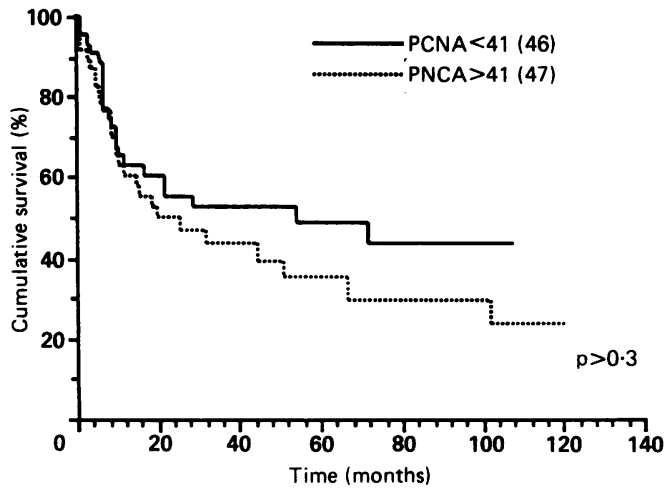

material for which follow up data are available. Recent reports suggest that this antibody may have a value in the histological grading of certain tumours and as an independent prognostic variable. ${ }^{10}{ }^{11}$ In this study PCNA index was unrelated to the histological appearances of the tumours and also did not correlate with depth of invasion or the presence of lymph node metastasis. Although patients with a high PCNA index seemed to have a slightly worse prognosis, this was not significant. These data suggest that the PCNA index measured with PC10 is unrelated to tumour behaviour: this is not altogether unexpected considering previous reports measuring proliferative activity in many human tumours. ${ }^{4}$ Using the monoclonal antibody $\mathrm{Ki}-67$ consistent results have only been obtained in lymphomas, higher $\mathrm{Ki}-67$ indices being found in tumours with higher grades of malignancy. ${ }^{4}$ In tumours of the breast ${ }^{20}$ and colon ${ }^{21} \mathrm{Ki}-67$ index has been found to be unrelated to any established clinical or pathological variables. This could be explained by the pronounced heterogeneity of these tumours compared with lymphomas, and this view is supported by $\mathrm{Ki}-67$ data on gastric carcinoma. ${ }^{22}$ In our material (unpublished observations) we find that the $\mathrm{Ki}-67$ and PCNA indices are broadly similar in the two groups of gastric carcinoma analysed. The $\mathrm{Ki}-67$ values show a mean intratumoural standard deviation of 9.0 rising to a maximum of 18.4 and indicating a significant level of intratumoural variation which is greater than the intratumoural values $(17 \cdot 2)$. The high degree of heterogeneity is likely to be responsible for the inconsistent results observed both with $\mathrm{Ki}-67$ and PCNA indices. The high intra- and inter-observer

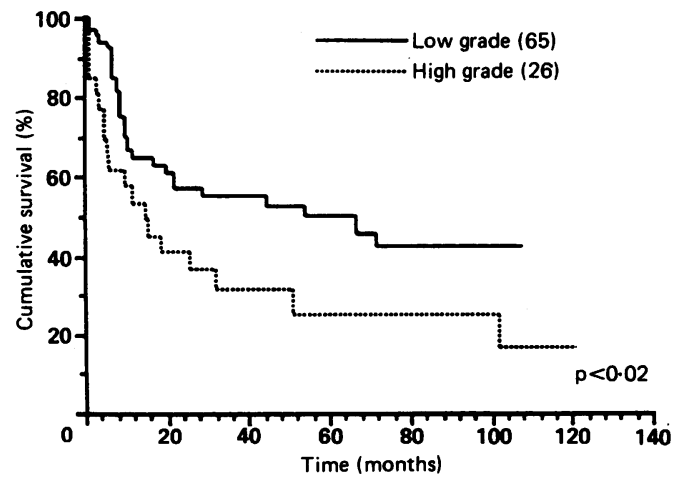

variations are almost certainly due to sampling differences in heterogeneous tumours.

Grading PCNA staining on a semiquantitative basis allowed us to take account of tumour heterogeneity. One could take this further and assess PCNA grade on several blocks of the tumour rather than do the assessment as we did on the most representative block. On the nine cases in which we assessed PCNA grade on two or more blocks, seven gave the same grade and two gave different grades between blocks. How to resolve this is arbitrary: one could accept the grade on the histologically most representative area; one could accept the overall majority grade on sections from several blocks; or one could record these tumours as of borderline grade. Overall, grading as recorded in this study on one block, showed a good correlation with the PCNA index and was unrelated to histological classification, depth of invasion, and presence of lymph node metastasis. The lack of correlation of these variables with proliferative activity, as shown in a larger series of gastric carcinomas by flow cytometric evaluation of $\mathrm{S}+\mathrm{G}_{2} \mathrm{M}$ phase, ${ }^{17}$ and as indicated by $\mathrm{Ki} 67$ indices (above), suggest that factors other than proliferative activity are also important in tumour behaviour.

Unlike the PCNA index, PCNA grade seemed to be a good predictor of prognosis with significant differences between low and high PCNA grade groups.

PCNA grading is assessed on the whole section. A PCNA index counted on the whole section would involve counting 10000 cells in some sections-about 20 hours of continuous concentration-not a practical proposition. The fact that there was a tendency for PCNA index to correlate with prognosis, however, raises the possibility that a full PCNA index (that is, counting of all the tumour cells in a section)-may correlate closely, as it should, with PCNA grade, and also therefore with prognosis. Our results indicate that PCNA grading may be a practical and useful compromise as a method for assessing overall PCNA staining and would allow for tumour heterogeneity. The antibody PC10, used in this way, may provide prognostically useful information in cases of gastric carcinoma.

We thank Dr Richard Morris, Public Health Medicine (UMDS Guy's Hospital) for his advice on statistical analysis.

1 Cancer Research Campaign. Facts on cancer? Factsheets 8, 9 , and 10, London: CRC, 1988

2 Munoz N. Descriptive epidemiology of stomach cancer. In Reed PI, Hill MJ, eds. Gastric carcinogenesis. Amsterdam: Elsevier Science Pubishers, 1988:51-69.

3 Ribeiro MM, Seixas M, Sobrinhjo-Simoes MA. Prognosis in gastric carcinoma. The pre-eminence of staging and the
futility of histological classification. Vol 1 In: Watanabe $S$, Wolf M, Sommers S, eds. Digestive disease pathology. Wolff M, Sommers S, eds. Digestive disease

4 Hhiladelphia: Field \& Wood Inc, $1988: 51-68$. all PA, Levison DA. Review: Assessment of cell proliferation in histological material. J Clin Pathol 1990;43:184-92.

5 Hall PA, Wood AL. Immunohistochemical markers of cellular proliferation: achievements, problems and prospects. Cell Tissue Kinet 1990;23:531-49.

6 Mattews B, Bernstein RM, Franza BR Jr, et al. Identity of the proliferating cell nuclear antigen and cyclin. Nature 1984;309:374-6.

7 Prelich G, Tan CK, Kotsura M, et al. Functional identity of proliferating cell nuclear antigen and a DNA polymerase-delta auxiliary protein. Nature 1987;326: 517-20. 
8 Waseem NH, Lane DP. Monoclonal antibody analysis of the proliferating cell nuclear antigen (PCNA). Structural conservation and the detection of a nucleolar form. $J$ Cell Sci 1990;96:121-9.

9 Hall PA, Levinson DA, Wood AL, et al. Proliferating cell nuclear antigen (PCNA) immunolocalisation in paraffin sections: An index of cell proliferation with evidence of deregulated expression in some neoplasms. J Pathol 1990; deregulated

$10 \mathrm{Yu} \mathrm{C}$, Hall PA, Fletcher CD, et al. Immunohistochemical staining with a monoclonal antibody to proliferating cell nuclear anti a monoclonal antibody to proliferating cell haemangiopericytomas. J Pathol 1990;161:342A.

11 Woods AL, Hanby AM, Hall PA, et al. The prognostic value of PCNA (proliferating cell nuclear antigen) immunostaining in gastrointestinal lymphomas. $J$ Pathol 1990;161:342A

12 Lauren $P$. The two main histological types of gastric carcinoma: Diffuse and so called intestinal-type carcinoma. Acta Pathol Microbiol Scand 1965;64:31-49.

13 Ming S. Gastric carcinoma: a pathobiological classification. Cancer 1977;39:2475-85.

14 Oota K, Sobin LH. Histological typing of gastric and oesophageal tumours. International histological classification of tumours. No. 18. Geneva: World Health Organisation, 1977.
15 Hedley DW, Friedlander ML, Taylor IW, Rugg CA, Musgrove EA. Method for analysis of cellular DNA content of paraffin-embedded pathological material using flow cytometry. J Histochem Cytochem 1983;31:1333-5.

16 Ormerod MG, Imrie PR. Flow cytometry. In: Pollard J, Walker JW, eds. Methods in molecular biology. Vol. 5, Clifton, NJ: Human Press; 1990:543-58.

17 Filipe MI, Rosa J, Sandey A, Imrie PR, Ormerod MG, Morris RW. Is DNA ploidy and proliferative activity of prognostic value in advanced gastric carcinoma? Hum prognostic value in ad

18 Peto R, Pike MC, Armitage P, et al. Design and analysis of randomized clinical trials requiring prolonged observation of each patient (II Analysis and examples) Br J Cancer 1977;35:1-39.

19 Cox DR. Regression models and life tables. $J$ Roy Statist (Sect B). 1972;34:187-220.

20 Bouzubar N, Walker KJ, Griffiths $\mathrm{K}$, et al. Ki-67 immunostaining in primary breast cancer: pathological and clinical associations. Br J Cancer 1989;59:943-7.

21 Shepherd NA, Richman PI, England J. Ki-67 derived proliferative activity in colorectal adenocarcinoma with proliferative activity in colorectal adenocarcinom

22 Yonemura Y, Ooyama S, Sugiyama K. Growth fractions in gastric carcinomas determined with monoclonal antibody Ki-67. Cancer 1990;65:1130-4. 